\title{
Membrane-Associated Progesterone Receptor Component 1
}

National Cancer Institute

\section{Source}

National Cancer Institute. Membrane-Associated Progesterone Receptor Component 1. NCI Thesaurus. Code C128475.

Membrane-associated progesterone receptor component 1 (195 aa, $\sim 22 \mathrm{kDa}$ ) is encoded by the human PGRMC1 gene. This protein may play a role in progesterone uptake. 